\title{
Multikinase Inhibitor AEE788
}

National Cancer Institute

\section{Source}

National Cancer Institute. Multikinase Inhibitor AEE788. NCI Thesaurus. Code C48369.

An orally bioavailable multiple-receptor tyrosine kinase inhibitor. AEE788 inhibits phosphorylation of the tyrosine kinases of epidermal growth factor receptor (EGFR), human epidermal growth factor receptor 2 (HER2), and vascular endothelial growth factor receptor 2 (VEGF2), resulting in receptor inhibition, the inhibition of cellular proliferation, and induction of tumor cell and tumor-associated endothelial cell apoptosis. ( $\mathrm{NCl05)}$ 